九州大学学術情報リポジトリ

Kyushu University Institutional Repository

\title{
Biomass Production and Lipid Content of Leptolyngbya HS-16 grown in Bubble Column Photobioreactors (BCPBR) with Air Bubbler Pore Variation
}

\section{Aliff Muhamad Or lando}

Department of Biology, Faculty of Mathematics and Natural Sciences, Universitas Indonesia

Nasruddin

Department of Mechanical Engineering, Faculty of Engineering, Universitas Indonesia

Sjamsuridzal, Wellyzar

Department of Biology, Faculty of Mathematics and Natural Sciences, Universitas Indonesia

Wardhana, Wisnu

Department of Biology, Faculty of Mathematics and Natural Sciences, Universitas Indonesia 他

https://doi.org/10.5109/4742137

出版情報：Evergreen. 8 (4)，pp.885-889，2021-12. 九州大学グリーンテクノロジー研究教育センター バージョン：

権利関係 : 


\title{
Biomass Production and Lipid Content of Leptolyngbya HS-16 grown in Bubble Column Photobioreactors (BCPBR) with Air Bubbler Pore Variation
}

\author{
Aliff Muhamad Orlando을 Nasruddin², Wellyzar Sjamsuridzal ${ }^{1}$, Wisnu Wardhana ${ }^{1}$, \\ Nining Betawati Prihantini ${ }^{1, *}$ \\ ${ }^{1}$ Department of Biology, Faculty of Mathematics and Natural Sciences, Universitas Indonesia, \\ Kampus UI Depok 16424, Indonesia \\ ${ }^{2}$ Department of Mechanical Engineering, Faculty of Engineering, Universitas Indonesia, \\ Kampus UI Depok 16424, Indonesia
}

*Author to whom correspondence should be addressed:

E-mail: nining.prihantini@gmail.com; nining@sci.ui.ac.id

(Received April 30, 2021; Revised December 16, 2021; accepted December 16, 2021).

\begin{abstract}
Research on the production of biomass and lipid content of Leptolyngbya HS-16 grown in a photobioreactor with variations in the number of air bubbles forming holes in the photobioreactor has been carried out. Photobioreactor (PBR) is a system designed to support the life of microorganisms in the system by providing various factors that can be used for growth such as light, carbon dioxide and nutrients. Bubble column photobioreactor (BCPBR) provides aeration for mixing nutrients and a carbon dioxide source for culture. In this study, two types of bubble column photobioreactor (BCPBR) were used with variations in the number of air bubbles, namely 12 (BCPBR1) and 24 (BCPBR2). In addition, TPBR without aeration was used as a control. This study used Leptolyngbya HS-16, an indigenous cyanobacteria isolated from Red Crater, Pancar Mount, West Java. Leptolyngbya HS-16 was inoculated on a bubble column photobioreactor (BCPBR). The lipids obtained from this strain were $4.41 \%$ (BCPBR1) and 1.30\% (BCPBR2) after 24 days.
\end{abstract}

Keywords: Indonesia; Indigenous cyanobacteria; Leptolyngbya; Lipid; Photobioreactor

\section{Introduction and background}

There are two types of energy, non-renewable and renewable energy. With the advancements on science and technology, people are turning their eyes to the renewable energy $^{1)}$. This also because each day, the non-renewable energy source depleted and one day the supply of nonrenewable energy source will run out ${ }^{2)}$. Scientists and experts around the world are starting to search for a renewable energy source for sustainable energy needs in the near future ${ }^{3)}$.

As we may know, people nowadays are starting to use a different kind of renewable energy source such as solar energy and wind energy. Beside of that, people also start using biofuel that can be produced from plants biomass like sugarcane and $\operatorname{corn}^{4}$. Besides plants biomass, biofuel also can be produced from microorganism biomass ${ }^{5}$. Microorganisms that can be used to produce biomass as a basic material for biofuels are microalgae. Microalgae that can be used are both members of eukaryotic and prokaryotic microalgae. One of the prokaryotic algae is the cyanobacteria.

Leptolyngbya is one of filamentous cyanobacteria ${ }^{6}$. Leptolyngbya can reproduce by forming vegetative cells called Hormogonia. Hormogonia are short filaments derived from long broken filaments, and function as asexual reproductive cells ${ }^{7}$.

The genus Leptolyngbya with strain code Hot Spring (HS)-number 16 is the microorganism used in this study. This indigenous microorganism is an isolate from Red Crater, Pancar Mountain that succesfully isolated by Prihantini $^{8)}$ on 2015. Leptolyngbya HS-16 is known to contain several types of lipids including saturated fatty acids by $40.56 \%$, monounsaturated fatty acids by $31.04 \%$, branched fatty acids by $25.67 \%$ and hydroxy-substituted fatty acids by $2.74 \%{ }^{9)}$. In addition, Leptolyngbia HS-16 can be grown on 80 ppm NPK fertilizer medium and produces a lipid content of $45 \%{ }^{10)}$. Lipid from 
Leptolyngbya can be used as feedstock to make biofuel after a series of processes. Microorganism biomass usually produced by inoculating microorganism to open system (open pond) or closed system (Photobioreactor) ${ }^{11)}$.

One of the functions of photobioreactors is to increase the production of microbial biomass by providing aeration or mixing of nutrients. The use of aeration causes every microorganism cell to get the same nutrients. Aeration can also provide carbon dioxide needed by microorganisms, especially microalgae/cyanobacteria.

Cyanobacteria culture requires a way to distribute nutrients in the growing medium in a photobioreactor system. Bubbling or aeration is one way that can be used to stir nutrients, especially for filamentous cyanobacteria $^{12)}$. Pre-research that has been carried out has proven that aeration can be used as a form of stirring for Leptolyngbya HS-16 which has a tendency to be benthic or easy to adhere to surfaces. However, pre-study on the growth of Leptolyngbya HS-16 with aeration as a form of agitation is still not optimal. The aeration provided is still not too evenly distributed because the design of the photobioreactor is still very simple. The research was conducted using a photobioreactor design with a bubbleforming aeration channel. The different variations in the number of bubble-forming holes may also affect the growth of cyanobacteria in this case Leptolyngbia HS-16. Therefore, in this study, two photobioreactors with different number of air bubbles were used. This study aims to determine the effect of differences in the number of air bubbles on the lipid production of Leptolyngbya HS-16.

\section{Method and experimental setup}

The treatment given to Leptolyngbya HS-16 was growing in two different types of the bubble column photobioreactor (BCPBR) using NPK [Grow More] as the growth medium. Tubular Photobioreactor (TPBR) without aeration was used as a control. Meanwhile, for the treatment using BCPBR with two variations of aeration channels (air bubble pores), each of which has 12 pores (BCPBR1) and 24 pores (BCPBR2). Each pores have 0.2 cm diameter.

Each PBR system is made into 3 units as a form of repetition. The number of units of the PBR system is 9 units. The nine units consisted of 3 units of TPBR without aeration, 3 units of BCPBR1, and 3 units of BCPBR1. The study was conducted for 15 days with data collection on day zero (t0) and continued until day 16 (t1, t2, t3, t4, t5, t6, t7, t9, t10, t12, t13, t14, t15 and t16).

The aeration are provided by using pipe that connected to an air compressor. Aeration are provided to mix the nutrients in the growth media ${ }^{13)}$. Beside mixing the nutrients, aeration also provide carbon dioxide needed by Leptolyngbya HS-16.



Fig.1 Bubble Column Photobioreactors Design with Different Variations of Air Bubbler Pores Amount

The medium used in the study was BG-11 medium and NPK [Grow More] medium with a concentration of 80 ppm. The BG-11 medium is used as an enrichment medium. The enrichment medium is a medium that has nutritional components that can only be used by specific microorganisms ${ }^{14)}$.

Biomass propagation is carried out to make stock cultures, work cultures and starter cultures. The Leptolyngbya HS-16 culture was inoculated into $100 \mathrm{~mL}$ of BG-11 medium NIES that had been provided in a 250 $\mathrm{mL}$ Erlenmeyer flask ${ }^{15)}$. The Erlenmeyer flask is then stored in an incubation cabinet with a temperature of 35 ${ }^{\circ} \mathrm{C}^{8)}$.

Leptolyngbya HS-16 biomass cultivated to NPK 80 ppm growth media with $\mathrm{pH}$ amount of 7.2 inside the BCPBR. NPK medium with a concentration of $80 \mathrm{ppm}$ requires $80 \mathrm{mg}$ of NPK in $1000 \mathrm{~mL}$ of distilled water. The NPK fertilizer used is NPK [GrowMore] ${ }^{16)}$.

Data collected in this research are Leptolyngbya HS-16 biomass weight and lipid content in the end of the observations. Observations of biomass weight last for 16 days. Weighing the weight of Leptolyngbya HS-16 biomass was carried out on the observations $t 0, t 1, t 2, t 3$, $\mathrm{t} 4, \mathrm{t} 5, \mathrm{t} 6, \mathrm{t} 7, \mathrm{t} 10, \mathrm{t} 13$ and $\mathrm{t} 16$. Weighing the biomass of Leptolyngbya HS-16 was started by weighing the sterile 2 $\mathrm{mL}$ eppendorf tube. The weight of dry biomass is obtained by drying the pellets in eppendorf in an oven at $40{ }^{\circ} \mathrm{C}$ for about 6 hours. The dried pellets are then weighed using analytical scales. Lipid content measurements were carried out using the Bligh \& Dyer $(1959)^{17)}$. method following the method in Addana 2014 ${ }^{18}$. Below are the equations to get the total lipid percentage ${ }^{19}$.

$$
\% \text { Total Lipid }=\frac{D L P(g)}{D C W(\mathrm{~g})} \times 100 \%
$$

\section{Results and Discussion}

\subsection{Biomass Weight and Growth Curve of Leptolyngbya HS-16}

The data of Leptolyngbya HS-16 biomass weight was collected on (t) t0, t1, t2, t3, t4, t5, t6, t7, t10, t13, and t16 
observation days. The number of starter cultures of Leptolyngbya HS-16 added to the test culture was $600 \mathrm{mg}$ in $1500 \mathrm{~mL}$ of medium. This was done to make each treatment get a uniform number of Leptolyngbya HS-16 cultures.

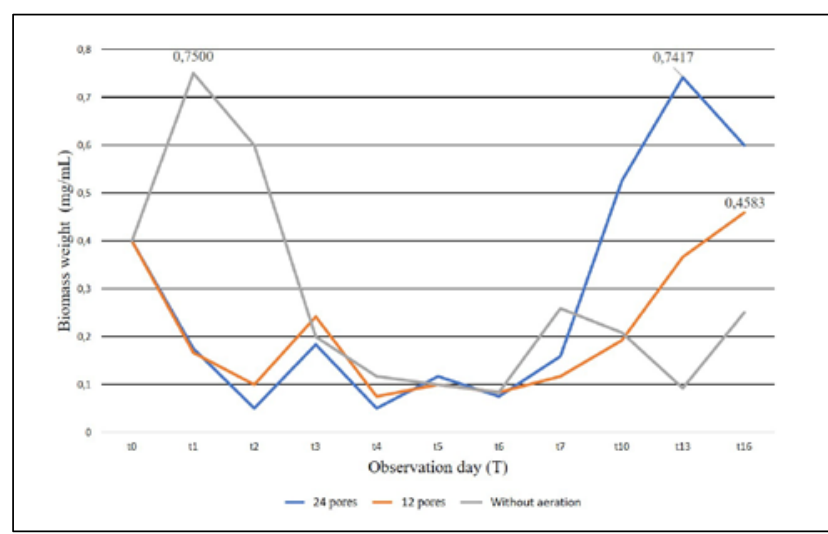

Fig. 2 Growth Curve of Leptolyngbya HS-16

Figure 2 shows the growth curves of Leptolyngbia HS16 grown on three photobioreactor systems. Based on Figure 2, the average weight of Leptolyngbya HS-16 biomass in the BCPBR system with the variation in the number of aeration channeling pores increased on the 4th day ( $t 4)$ of observation. The increase in growth continued until t13 in the BCPBR system with 24 pores (BCPBR2) reached the peak or average weight of Leptolyngbya HS16 biomass which was higher than the BCPBR system with 12 pores (BCPBR1). Meanwhile, the average weight of Leptolyngbya HS-16 biomass in the TPBR system without aeration increased at $\mathrm{t} 1$ and decreased at $\mathrm{t} 2$.

The average weight of Leptolyngbya HS-16 biomass in the BCPBR system with 24 pores (BCPBR2) has a higher average weight of biomass when compared to the average weight of Leptolyngbya HS-16 biomass in the TPBR system without aeration at $\mathrm{t} 13$. These results showed that Leptolyngbya HS-16 was able to grow better in the BCPBR2 compared to the TPBR system without aeration. Meanwhile, the BCPBR1 still experienced an increase in biomass growth up to t16.

The highest mean dry biomass weight was obtained at TPBR without aeration on the 1st observation day (t1) of $0.7500 \mathrm{mg} / \mathrm{mL}$. Meanwhile, the highest average dry biomass weight in BCPBR with 24 pores (BCPBR2) was obtained at $\mathrm{t} 13$ of $0.7417 \mathrm{mg} / \mathrm{mL}$ and the highest average dry biomass weight in BCPBR with 12 pores (BCPBR1) was obtained at t16 of $0.4583 \mathrm{mg} / \mathrm{mL}$. The increase followed by a decrease in the average weight of biomass in TPBR without aeration is a form of adaptation of Leptolyngbya HS-16 when introduced into a new medium $^{20)}$. The decrease in mean weight of biomass in TPBR without aeration may occur due to reduced nutrients that can be used by Leptolyngbya HS-16. In addition, the decrease that occurs can also occur due to a lack of carbon dioxide sources, causing the rate of photosynthesis to be hampered. The decrease that occurs in BCPBR with variations in bubble-forming holes can occur because aeration which creates a stirring effect can make Leptolyngbya HS-16 unable to form mats at the beginning of the observation. The adaptation phase that occurs in BCPBR with variations in bubble-forming holes may occur from t1 to t6 which shows an increase to t13 for BCPBR with 24 pores (BCPBR2) and t16 for BCPBR with 12 pores (BCPBR1).

From the figure 2 above, we know that Leptolyngbya HS-16 that cultured in BCPBR2 produce more biomass rather than the one that cultured in BCPBR1. That could happen because the nutrients in BCPBR2 are mixed better rather than in BCPBR1 ${ }^{21)}$. The amount of bubbles can also affect microorganism growth in photobioreactor because the bubbles can cause shear stress, and it will break the cells ${ }^{22)}$.

\subsection{Lipid Content of Leptolyngbya HS-16}

Measurement of the lipid content of Leptolyngbya HS16 was carried out at the end of the observation (t16). Lipid content testing was carried out on 24-day-old cultures. The lipid content of Leptolyngbya HS-16 in different treatments had different amounts. Based on the measurement results, it is known that the lipid content of Leptolyngbya HS-16 in the BCPBR2 system is $1.30 \%$ with a biomass weight of $0.6 \mathrm{mg}$ and a lipid weight of 46.2 mg; while the lipid content of Leptolyngbya HS-16 in the BCPBR1 system was $4.41 \%$ with a biomass weight of 2.9 $\mathrm{mg}$ and a lipid weight of $65.8 \mathrm{mg}$. Meanwhile, the lipid content of Leptolyngbya HS-16 in the TPBR system without aeration was $15.23 \%$ with a biomass weight of 3.9 $\mathrm{mg}$ and a lipid weight of $25.6 \mathrm{mg}$. The results of the measurement of lipid content are listed in table 1.

Table 1 Data on lipid content of Leptolyngbya HS-16

\begin{tabular}{c|c|c|c}
\hline Treatment & $\begin{array}{c}\text { Lipid } \\
\text { weight } \\
(\mathrm{mg})\end{array}$ & $\begin{array}{c}\text { Biomass } \\
\text { weight } \\
(\mathrm{mg})\end{array}$ & $\begin{array}{c}\text { Lipid } \\
\text { content } \\
(\%)\end{array}$ \\
\hline 24 Pores (BCPBR2) & 0.6 & 46.2 & 1.30 \\
\hline 12 Pores (BCPBR1) & 2.9 & 65.8 & 4.41 \\
\hline without aeration & 3.9 & 25.6 & 15.23 \\
\hline
\end{tabular}

The results are quite small rather than a few research done by another researcher. Singh et.al. (2014) get lipid percentage $16-21 \%$ of dry biomass weight ${ }^{23}$. Tsolcha et.al. (2018) get lipid percentage $14.8 \%{ }^{24}$. Meanwhile, Maity et..al. (2018) get lipid percentage $31.34 \%^{25)}$. This could happen because there is mucilage production that occur due to shear stress or another environment stress ${ }^{26)}$.

Mucilage which is a carbohydrate compound can not be dissolved and does not evaporate when the chloroform and metanol compound was applied to dilute cell wall. The mucilage will remain and become one with dry biomass weight ${ }^{27)}$. Basically, mucilage is produced to form cell sheath. Mucilage also have function as the 
backbone of mats in mats forming microorganism ${ }^{28)}$.

\section{Conclusions}

The average biomass of Leptolyngbya HS-16 produced on BCPBR2 have more amount rather than on BCPBR1. In other hand, the lipid percentage are higher in BCPBR1 rather than on BCPBR2. Consideration in using the different type of BCPBR are important, due to its function in production. More improvement is needed to increase the biomass and lipid production on each of BCPBR.

\section{Acknowledgements}

This research was funded by Penelitian Dasar Unggulan Perguruan Tinggi Grant (PDUPT) by Ministry of Research and High Education (Kemenristek Dikti) Fiscal Year of 2019 to Dr. Nining Betawati Prihantini, M.Sc. with grant no. NKB-1605/UN2.R3.1/HKP.05.00/2019.

\section{Nomenclature}

DLP Dry lipid

DCW Dry cell weight $(\mathrm{mg} / \mathrm{mL})$

\section{References}

1) T. Hanada. Modifying the Feed-in Tariff System in Japan: An Environmental Perspective. EVERGREEN Joint Journal of Novel Carbon Resource Sciences \& Green Asia Strategy 5 (2). 54-58 (2016).

2) M. K. Barai, and B. B. Saha. Energy Security and Sustainability in Japan. EVERGREEN Joint Journal of Novel Carbon Resource Sciences \& Green Asia Strategy 2 (1). 49-56 (2015).

3) G. J. Suppes, and T. Storvick. Sustainable Nuclear Power (1 $1^{\text {st }}$ ed.). Academic Press, Columbia, p 416 (2006).

4) M. Ayadi, S, Ahou, S. Awad, M. Abderrabba, and Y. Andres. Production of Biogas from Olive Pomace EVERGREEN Joint Journal of Novel Carbon Resource Sciences \& Green Asia Strategy 7 (2).228233 (2020).

5) S.R. Ardiansyah, A. M. Orlando, A.Rahman, N. B. Prihantini, and Nasruddin. Tubular Photobioreactor: A Preliminary Experiment Using Synechococcus sp. (Cyanobacteria) Cultivated in NPK Media for Biomass Production as Biofuel Feedstock. EVERGREEN Joint Journal of Novel Carbon Resource Sciences \& Green Asia Strategy 6 (2).157161 (2019).

6) J. Komarek. Phenotype diversity of the cyanobacterial genus Leptolyngbya in the maritime Antarctic. Polish polar research. 3:211-231. (2007).

7) L. E. Graham, and L. W. Wilcox. Algae. Upper Saddle
River, Prentice Hall, New Jersey, p 640 (2000).

8) N. B. Prihantini. Polyphasic Taxonomy of Culturable Cyanobacteria Isolated from Hot Springs in West Java, Indonesia. Dissertation Department of Biology, Faculty of Mathematics and Natural Sciences, Depok, p. 115. (2015).

9) N.B. Prihantini, S. Handayani, W. Sjamsuridzal, A. Yokota, and Nasruddin, "Fatty acid characterization of indigenous cyanobacterial strains isolated from five hot springs in indonesia,” E3S Web Conf., 67 02021 (2018). doi:10.1051/e3sconf/20186702021.

10) N. B. Prihantini, N. Rakhmayanti, S. Handayani, W. Sjamsuridzal, W. Wardhana, and Nasruddin. Biomass Production of Indonesian Indigenous Leptolyngbya Strain on NPK Fertilizer Medium and its Potential as a Source of Biofuel. EVERGREEN Joint Journal of Novel Carbon Resource Sciences \& Green Asia Strategy 7 (4). 593-601 (2020).

11) M. El-Sheekh, and A. F. Abomohra. Biodiesel production from microalgae. In: Garg, N. \& A. Aeron. (ed.). 2016. Industrial microbiology: microbes in action. Nova Science Publishers, United Kingdom, (2016).

12) Y. Pouliot, G. Buelna, and J . Racine C de la Noüe. Culture of cyanobacteria for tertiary wastewater treatment and biomass production. Biol. Waste., 29: 81-91 (1989).

13) G. Markou, and D. Georgakakis. Cultivation of filamentous cyanobacteria (blue-green algae) in agroindustrial wastes and wastewaters: A review. Applied Energy 88(10): 3389-3401. (2011).

14) G. J. Tortora, B. R. Funke, and C. L. Case. Microbiology: An Introduction (10 ${ }^{\text {th }}$ ed.). Pearson Benjamin Cummings, San Fransisco, p 812 (2010).

15) NIES. NIES-Collection List of Strains $6^{\text {th }}$ edition Microalgae and Protozoa. National Institute of Environtmental Studies. Tsukuba, p. v +159. (2007).

16) Grow More. 2013. Water soluble fertilizer. http://www.growmore.com/products/type/watersoluble-fertilizer.html\#, (accessed March 8, 2018).

17) E. G. Bligh, and W. J. Dyer. A rapid method of total lipid extraction and purification. Canadian Journal of Biochemistry and Physiology. 37: 911—917. (1959).

18) F. Addana, Pengaruh penggunaan ekstrak kompos sebagai medium kultur terhadap pertumbuhan produksi lipid Nannochloropsis sp. Skripsi Sarjana S1 Departemen Biologi, FMIPA, Universitas Indonesia, Depok, p. 96. (2014).

19) Y. Li, M. Horsman, B. Wang, and N. Wu. Effect of nitrogen sources on cell growth and lipid accumulation of green algae Neochloris oleoabundanss. Applied Microbiol Biotechnology. 81: 629—636. (2008).

20) M. Madigan, J. Martino, K. Bender, D. Buckley, and D. Stahl. Brock Biology of Microorganisms. $14^{\text {th }}$ ed. Pearson Education. United States of America, p. 1030. 
(2015).

21) A. M. Orlando, S. R. Ardiansyah, A. Rahman, N. B. Prihantini, and Nasruddin. Effects of aeration intensity as agitation in simple photobioreactors on Leptolyngbya (cyanobacteria) growth as biofuel feedstock. E3S Web of Conferences, 67(02011) (2018).

22) Z. Yang, H. Pei, F. Han, Y. Wang, Q. Hou, and Y. Chen. Effects of air bubble size on algal growth rate and lipid accumulation using fine-pore diffuser photobioreactors. Algal Research, 32: 293, (2018).

23) J. Singh, R. Tripathi, and I. S. Thakur. Characterization of endolithic cyanobacterial strain, Leptolyngbya sp. ISTCY101, for prospective recycling of $\mathrm{CO}_{2}$ and biodiesel production. Bioresource Technology, 166: 345-352. (2014).

24) O. N. Tsolcha, A. G. Tekerlekopoulou, C. S. Akratos, G. Antonopoulou, G. Aggelis, S. Genitsaris, M. Moustaka-Gouni, and D.V. Vayenas. A Leptolyngbyabased microbial consortium for agro-industrial wastewaters treatment and biodiesel production. Environmental Science and Pollution Research, 25(18):17957-17966 (2018).

25) J. P. Maity, Chia-P. Hou, D. Majumder, J. Bundschuh, T. R. Kulp. Chien-Y. Chen, Lu-T. Chuang, Ching-N. N. Chen, Jiin-S. Jean, Tsui-C. Yang, and Chieng-C. Chen. The production of biofuel and bioelectricity associated with wastewater treatment by green algae. Energy, 78: 94-103. (2014).

26) F. Rossi, and R. de Philippis. Role of Cyanobacterial Exopolysaccharides in Phototrophic Biofilms and in Complex Microbial Mats. Life, 5: 1222 (2015).

27) D.M. Mahlmann, J. Jahnke \& P. Loosen.. Rapid determination of the dry weight of single, living cyanobacterial cells using the Mach-Zehnder doublebeam interference microscope, European Journal of Phycology, 43(4): 360 (2008).

28) A. K. Srivastava, A. N. Rai \& B. A. Neilan. Stress Biology of Cyanobacteria: Molecular Mechanisms to Cellular Responses (1st ed.). CRC Press, Boca Raton, p 361. (2017). 